\title{
Analysis of Mathematical Communication Ability in Learning Proportion Topic Using Scientific Approach
}

\author{
Risna Zulfa Musriroh ${ }^{1 *}$, Abd. Qohar ${ }^{1}$ \\ ${ }^{1}$ Mathematics Education, State University of Malang \\ ${ }^{*}$ Corresponding author.Email: risna.zulfa.1803118@students.um.ac.id, abd.qohar.fmipa@um.ac.id
}

\begin{abstract}
Communication is an important aspect in learning mathematics. In the process of learning mathematical communication, there is a standard communication process that must be met. The purpose of this study was to describe mathematical communication ability on direct proportion topic and inverse proportion topic using a scientific approach and to explain the factors inhibiting mathematical communication ability. The design of this research was qualitative descriptive research. The instruments used were lesson plans, modules, worksheets, and documentation. The research results that were obtained included achievement of mathematical communication process standards such as (1) organizing and consolidating students' mathematical thinking through communication, (2) communicating students' mathematical thinking coherently (logically) and clearly to friends, teachers, and others, (3) analyzing and evaluating mathematical thinking and strategies used by others, and (4) using mathematical language to show mathematical ideas appropriately in each peer teaching activity.
\end{abstract}

Keywords: mathematical communication, proportion topic, scientific approach

\section{INTRODUCTION}

In the 2013 Curriculum, a scientific approach consisting of 5M (Observing, Asking, Digging Information, Associating, Communicating) is a learning approach that is necessary or even compulsory to be applied in all subjects, including mathematics [2]. Without mathematical communication ability, students will not be able to convey their mathematical ideas to others. The development of communication has also become one of the goals of mathematics learning and has become one of the competency standards for graduates in mathematics field. Through mathematics learning, students are expected to be able to communicate ideas with symbols, tables, diagrams, or other media to clarify the situation or problem in accordance with Permendiknas Number 20 of 2006 concerning Content Standards [14].

Students must learn to communicate using mathematical language because if students can communicate mathematical procedures verbally through discourse with classmates and teachers, even with their family and friends, and in writing through journals or portfolios, then they have demonstrated their understanding of concepts that are studied and discussed in class [8]. The importance of having mathematical communication ability is also explained by Clark, Jacobs, Pittman, \& Borko mathematical communication is a way of sharing ideas and clarifying understanding [4]. Through communication, ideas can be reflected, improved, discussed, and developed [1]. The communication process also helps build meaning and permanent ideas, and the communication process can also explain many ideas. Asikin \& Junaedi argue that mathematical communication ability has an important role in mathematics learning because it is (1) means to exploit mathematical ideas and help students' ability to see the various relationships of material in mathematics, (2) an instrument to measure growth in understanding and reflect mathematical understanding of students, (3) an instrument for organizing and consolidating students' mathematical thinking, and (4) an instrument for constructing mathematical knowledge, developing problem solving, improving reasoning, fostering self-confidence, and enhancing social skills [3].

Communication is a way of sharing ideas and clarifying understanding [9]. Huggins argues that to improve mathematical conceptual understanding is by expressing mathematical ideas to others [12]. The ability to express the idea of mathematical material to others both verbally and in writing is called mathematical communication ability or skill. Through communication, ideas can be reflected, improved, discussed, and developed. Sumarmo reveals that indicators of mathematical communication are: (1) Connecting real objects, pictures and diagrams into mathematical ideas, (2) Explaining ideas, situations and mathematical relationships verbally in writing with real objects, graphs, and diagrams, (3) Stating daily events in mathematical language or symbols, (4) Listening, discussing, and writing about mathematics, (5) Reading with understanding of a written mathematical presentation, (6) Making a conjecture, compiling arguments, formulating definitions and generalizations [7]. The teaching material in this research was proportion topic taught in class VIII semester I. Thus, the formulation of the problem in this study is how the student's mathematical communication ability is in accordance with the NCTM (The National 
Council of Teachers of Mathematics) 2000 process. The purpose of this study is to describe student's mathematical communication ability on direct proportion and inverse proportion in science approach learning.

The process and results of student worksheets can be analyzed based on the standard of mathematical communication process in NCTM 2000 including are (1) organizing and consolidating students' mathematical thinking through communication, (2) communicating students' mathematical thinking coherently (logically) and clearly to friends, teachers, and others, (3) analyzing and evaluating mathematical thinking and strategies used by others, and (4) using mathematical language to show mathematical ideas appropriately [13]. Then the analysis of student's mathematical ability according to the process standard in NCTM 2000 is strengthened by the indicators put forward by various experts who have researched about mathematical communication.

\section{METHOD}

This research was a qualitative descriptive study, which aimed at describing the communication process standard in learning mathematics with direct proportion and inverse material using scientific approach. The researchers prepared lesson plans and then applied the learning in peer teaching. The learning design and the application were reviewed and analyzed. Mathematical communication ability could be analyzed based on the workmanship of the worksheet according to the group discussion process, presentation in front of the class, and solving proportion problems with group discussions using spoken and written language.

The instruments used in this study were lesson plans, modules, LKS or worksheets, which were used to record the important things not recorded on the other instrument, and documentation of activity pictures during the study as the evidence that the research was actually implemented. The indicator used as a guideline for testing mathematical communication ability was according to NCTM 2000.

\section{RESULT AND DISCUSSION}

\subsection{Organizing and Consolidating Students' Mathematical Thinking through Communication}

The first standard achievement of the mathematical communication process was communication of students within organizing and consolidating through mathematical thinking, namely by learning cooperative learning with peers in one group. In this case, it fulfilled the indicators put forward by Sumarmo, are namely listening, discussing, and writing about mathematics and indicators in NCTM 2000, namely the ability to express mathematical ideas through oral, written and demonstrate and visualize them. In detail we can see it from the results of group work in completing activity 1 .

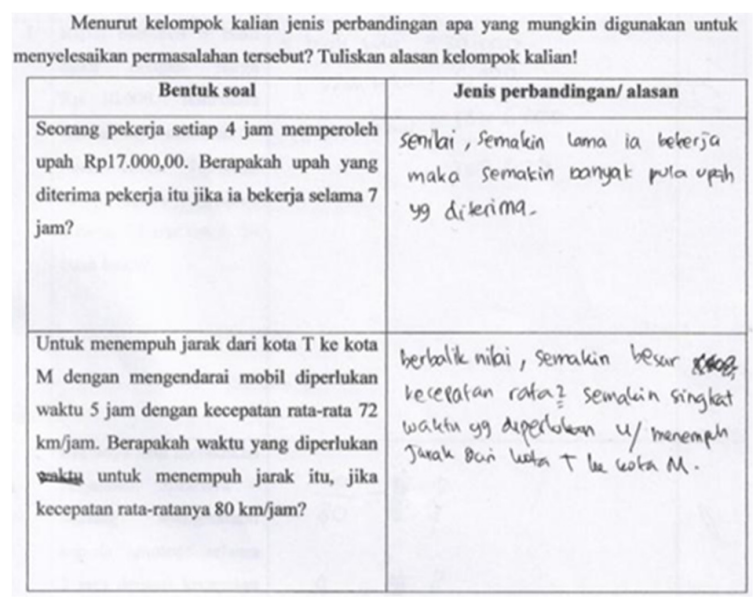

Figure 1 Discussion Result of Activity Sheet 1.

The result work of one group also showed an indicator that expressed daily events in mathematical language or symbols. Based on group discussion, students could distinguish the types of direct proportion or inverse proportion accompanied by reasons that supported the answers. According to Coronata \& Angel, communication is ultimately a tool that encourages interaction with others to clarify mathematical ideas, to strengthen communication, ideas to become objects of reflection, precision and discussion [5]. In addition, by communicating with arguments, students learn to be clear and convince in the use of mathematical language, and at the same time, to listen to the explanation of others, deepen their own understanding of mathematical ideas.

\subsection{Communicating Students' Mathematical Thinking Coherently (Logically) and Clearly to Friends, Teachers, and Others}

The next was thinking coherently or logically and clearly for communicate students' mathematical ideas to teachers, friends, and others by conveying individual thoughts in group discussions and then presenting them in front of the class. In this case it fulfilled the indicators put forward by Sumarmo namely explaining ideas, situations and mathematical relations, verbally in writing with real objects, graphs, and diagrams and reading and stating with an understanding of a mathematical presentation in writing. The details can be seen from the results of the group work presented to the class as follows: 


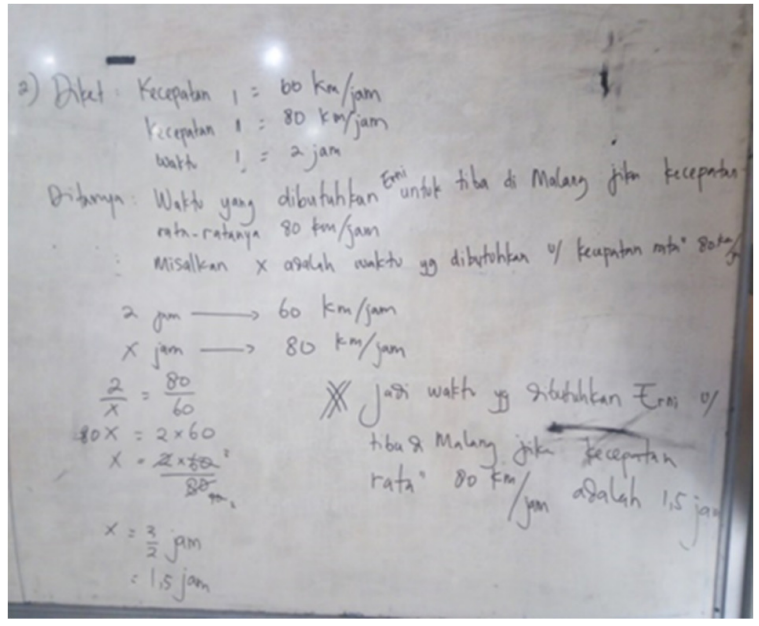

Figure 2 Discussion Results on Activity Sheet 2 Presented.

In addition, the teacher also guided the discussion in class and other groups also responded to the groups of presenters on the results of the discussion and provided responses. According to Paridjo and Waluya in general, mathematics in the sphere of communication includes the skills or abilities to write, read, discuss and assess, and convey knowledge or discourse [11]. Without communication in mathematics we will have little information, data, and facts about students in the process of understanding and applying mathematics.

\subsection{Analyzing and Evaluating Mathematical Thinking and Strategies Used by Others}

From the results of the group presentations, other groups and the teaching team were welcome to analyze and evaluate result of others through their strategies and mathematical thinking to achieve the communication process standard. The different ways of working on Activity 2 led to discussion inter groups. In this case communication occurred when group 2 was working on activity 2 and another group was conveying another way of working on the problem as follows:

\begin{tabular}{|c|c|c|}
\hline No & Soal & Langkah Penyelesaian \\
\hline 1 & $\begin{array}{l}\text { Randi membeli } 5 \text { buah } \\
\text { buku dengan harga } \\
\text { Rp. } 30.000,- \text {. sementara } \\
\text { Ghafar ingin membeli } 50 \\
\text { buah buku. Tentukan } \\
\text { berapa rupiah yang harus } \\
\text { dibayar Ghafar untuk } 50 \\
\text { buah buku? }\end{array}$ & $\begin{aligned} 5 \text { buah buleu } & =30.000 \\
1 \text { buah boke } & =6.000 \\
50 \text { buah buke } & =50 \times 6000 \\
& =300.000\end{aligned}$ \\
\hline
\end{tabular}

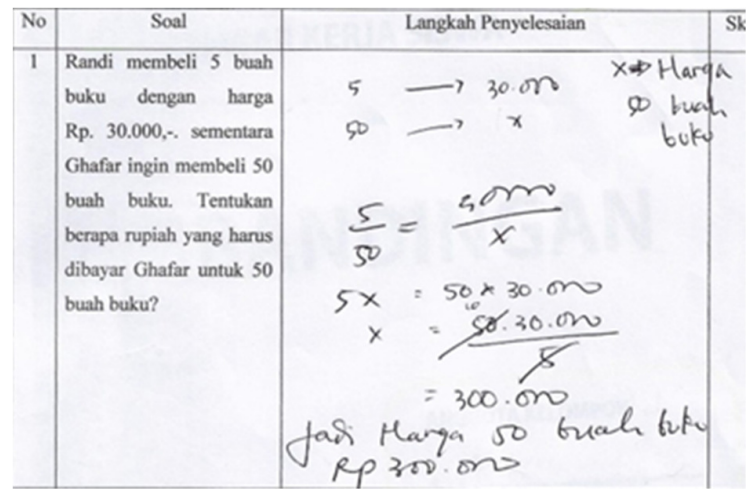

Figure 3 Results of Group Discussion Evaluated by Other Groups.

The success of communication in achieving the process standard was in accordance with research that mathematical communication skill was shown by: (1) students were able to express ideas with mathematical sentences verbally, (2) students were actively involved in discussions about mathematics, (3) students could formulate definitions and generalizations about mathematics, (4) students could formulate mathematical definitions using their own words [10].

\subsection{Using Mathematical Language to Show Mathematical Ideas Appropriately in Each Peer Teaching Activity.}

Achievement of process standard to show students' ideas of mathematics material use mathematical language was precisely demonstrated by the evaluation of other groups such as the results of work on the following activity 2 :

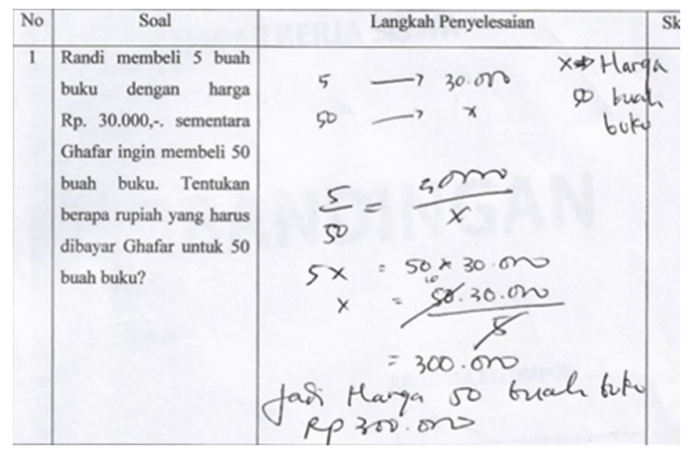

Figure 4. Conveying Mathematical Ideas in Activity 2.

Writing mathematics was shown by the answer to the problem on direct proportion. Writing mathematical ideas provided a way for students to gain insight about abstract concepts through drawing and other means of creative expression and experiments. It also allowed students to 
communicate their ideas to others, including their teachers and friends [6]. Mathematically, the results of group discussions used the concept of a reasonable and clear relationship, and were arranged logically and systematically. Indicators achieved in this process standard were connecting real objects or cases in daily life into mathematical concepts. Next was compiling arguments, formulating stages systematically according to the direct proportion equation. It was also the ability to use terms, mathematical notations and structures to present ideas, describe relationships with situation models shown by the use of formulas explicitly so that a solution was found.

\section{CONCLUSION}

Peer teaching activities on direct proportion and inverse proportion topics grades in class VII with a scientific approach meet the mathematical communication process standards according to NCTM 2000, namely (1) organizing and consolidating students' mathematical thinking through communication, (2) communicating students' mathematical thinking coherently (logically) and clearly to friends, teachers, and others, (3) analyzing and evaluating mathematical thinking and strategies used by others, and (4) using mathematical language to show mathematical ideas appropriately.

The 2013 curriculum is designed in accordance with the application of communication process standard. However, there is a possibility that the process standard will not go according to plan. Thus, the teacher acts as a mediator for the achievement of mathematical communication.

\section{REFERENCES}

[1] Ansari, B. I. 2009. Komunikasi Matematik. Yayasan Pena: Banda Aceh.

[2] As'ari, A.R. 2014. Berbagai Permasalahan Pembelajaran Matematika dalam Kurikulum 2013, dan Beberapa Upaya untuk Mencoba Mengatasinya, Seminar Nasional: Solusi Problematika Implementasi Kurikulum 2013 untuk Mewujudkan Pembelajaran yang Berkualitas.

[3] Asikin, M \& Junaedi, I. 2013. Kemampuan Komunikasi Matematika Siswa SMP dalam Setting Pembelajaran RME (Realistic Mathematisc Education). UJMER. Vol. 2. No. 1.

[4] Clark, K. K., Jacobs, J., Pittman, M. E., Borko, H. 2005. Strategies for Building Mathematical Communication in the Middle School Classroom: Modeled in Professional Development, Implemented in the Classroom. Current Issues in The Middle level education 11(2), 1-12.

[5] Coronata, C. \& Angel, A. 2014. Evaluation of The Mathematical Processes in The Practices of Teaching and Learning in Childhood Education. Procedia - Social and Behavioral Sciences. 141(2014): 1320 - 1323.

[6] Freeman, B., Higgins, K. N., Horney, M. 2016. How Students Communicate Mathematical Ideas: An Examination of Multimodal Writing Using Digital Technologies. Contemporary Educational Technology. 7(4): 281-313.

[7] Husna, Ikhsan, M., Fatimah, S. 2013. Peningkatan Kemampuan Pemecahan Masalah Dan Komunikasi Matematik Siswa SMP Melalui Model Pembelajaran Kooperatif Tipe Think-Pair-Share (TPS), Jurnal Peluang. 1(2): 2302-5158

[8] Lomibao, L. S., Luna, C. A., Namoco, R. A. 2016. The Influence of Mathematical Communication on Student's Mathematics Performance and Anxiety. American Journal of Educational Research. 4(5): 378-382.

[9] Machin, A. 2014. Implementasi pendekatan saintifik, penanaman karakter dan konservasi pada pembelajaran materi pertumbuhan SMA Negeri 1 Dempet, Demak. Jurnal Pendidikan IPA Indonesia, 3(1), 28-35.

[10] Nartani, C. I., Hidayat, R. A., Sumiyati, Y. 2015. Communication in Mathematics Contextual.

International Journal of Innovation and Research in Educational Sciences. 2(4): 284-287.

[11] Paridjo \& Waluya, St. B. 2017. Analysis Mathematical Communication Skills Students In The Matter Algebra Based Nctm. IOSR Journal of Mathematics (IOSR-JM). 13(1): 60-66.

[12] Qohar, A. 2011. Mathematical Communication: What And How To Develop It in Mathematics Learning? Proceeding International Seminar and the Fourth National Conference on Mathematics Education 2011. Yogyakarta: Universitas Negeri Yogyakarta.

[13] The National Council of Teachers of Mathematics (NCTM). 2000. Principles and Standarts for School Mathematics. Amerika Serikat. The National Council of Teachers of Mathematics, Inc.

[14] Wijaya, A. 2012. Pendidikan Matematika Realistik. Graha Ilmu: Yogyakarta. 